\title{
PERFORMANCE EVALUATION OF DEVELOPMENT FINANCIAL INSTITUTIONS - A CASE STUDY OF KSFC
}

\author{
*Inchara P. M Gowda
}

\begin{abstract}
:
Micro, Small and Medium Enterprises (MSMEs) are playing a stupendous role in the overall development of Indian economy. This is true even in the case other economies in the World. However, these enterprises have not been able to utilize their full potential to contribute for further development of the economy owning to many a number of problems. One such problem, of course a dominant problem, is the financial problem. The Development Financial Institutions (DFIs) such as Karnataka State Financial Corporation (KSFC) have become, to a greater extent, a panacea for the financial tribulations of MSMES. In this backdrop, this paper makes an attempt to examine the performance of KSFC in terms of a few parameters such as number of new and existing industrial enterprises in MSME sector assisted, amount of assistance, interest expense, interest income, net interest spread, profit after tax, etc.
\end{abstract}

Key Words: DFIs, KSFC, MSMEs, Net Interest Spread, Term Borrowings and Term Loans

\section{Introduction}

Micro, Small and Medium Enterprises (MSMEs) are playing a pivotal role in the overall development of Indian economy. They focus on many a number of laudable objectives such as generation of employment opportunities, diffusion of economic power in the hands of a few, undertaking low importintensive production activities, earning foreign exchange, higher contribution to domestic production, lower investment requirements, operational flexibility, import substitution, export promotion, etc. And the MSMEs are in both manufacturing and service sectors. Few facts presented below signify their importance and contribution to the Indian economy (Prime Minister's Task Force, 2010).

They (MSMEs) contribute about $45 \%$ to the industrial output and the exports from MSMEs account for $40 \%$ of total exports. They have generated 4.1 crore jobs - generating 10 lakh jobs every year - second largest employer next only to agriculture. They are producing more than 8,000 products for both Indian and international markets. They are contributing to the extent of $8.9 \%$ to the country's GDP.

Therefore, these enterprises are rightly called the backbone of India's GDP (Ruchika Jeswal, 2012). Though these MSMEs are contributing

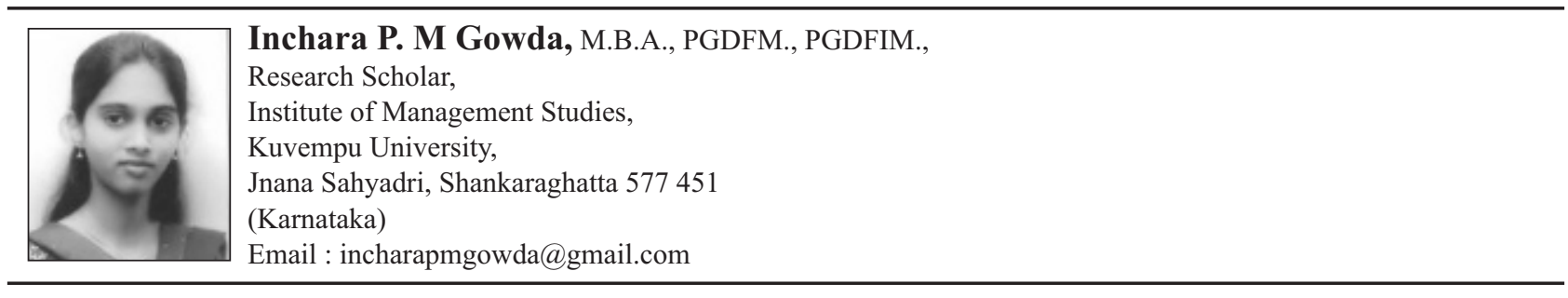


substantially, they are facing many a number of problems including financial problems. The financial problems of MSMEs include, among others, lack of availability of adequate and timely credit, high cost of credit, collateral requirements, and limited access to equity capital. This (i.e., financial problem) is one of the major and common problems of over 1.1 crore MSMEs in the country accounting for about $90 \%$ of the industrial units in the country. The Government of India and the state governments which realized the problems of MSMEs took the necessary steps to establish the financial institutions to provide mediumand long-term credit to these enterprises which fall outside the scope of normal activities of commercial banks. As a result, one can find many a number of development financial institutions in the country.

\section{Development Financial Institutions}

More or less, the entire Indian banking sector is fairly matured in terms of any of the relevant parameters used to evaluate the performance of banking sector such as products, services, automation, expansion, presence in rural areas, ability to face competition, etc. However, most of these banking institutions do not finance the business units in their medium- and long-term fund requirements. Of course, these banking institutions provide loans and advances to the businessmen/units but only on a small scale and for short duration - to meet their working capital requirements. Hence, there was a need for the banking and financial institutions meant to serve the industrial enterprises in their financial requirements. Therefore, the governments took necessary steps to establish development banks and other financial institutions to provide medium- and long-term funds to industrial enterprises including MSMEs for development and expansion purposes. In this background, Industrial
Development Bank of India (IDBI), 1 Industrial Credit and Investment Corporation of India (ICICI), 2 Industrial Finance Corporation of India (IFCI),3 etc., were established at the national level and State Financial Corporations at the state level. Karnataka State Financial Corporation is one such financial corporation established by the Government of Karnataka to provide varieties of financial services including medium- and long-term fund to MSMEs in the state of Karnataka.

\section{Karnataka State Financial Corporation}

Karnataka State Financial Corporation (KSFC) is a state level financial institution established way-back in 1959 (on 30 March 1959) by the state government under Section 3 of The State Financial Corporations Act, 1951. Up to 1 November 1973, it was called, Mysore State Financial Corporation. Government of Karnataka is the major shareholder $(94.13 \%)$ followed SIDBI (5.83\%) and others such insurance companies, public sector banks, cooperative societies and banks $(0.04 \%)$. As the coverage of its activities extends over the entire state, it has four circles, 4 seven zonal offices 5 and 32 branch offices (all all District headquarters with more than one branch office in Bengaluru).

The primary objective of KSFC is to meet the medium- and long-term financial requirements of MSMEs in the state. During this 57-year period, it has expanded its activities substantially as a responsive financial institution. It has re-engineered itself to ensure customer satisfaction with new schemes, strategies, transparency, etc. The corporation has contributed substantially towards the establishment and growth of MSMEs, development of industrially backward areas of the state and the promotion of first generation entrepreneurs. Though the primary objective of 
KSFC is lending money to the business units, it has expanded and diversified, over the years, its activities to provide all types of financial assistances such as loans short, medium and long-term loans, lease finance, hire purchase finance, merchant banking, financial services, etc. Further, it provides financial assistance to almost all types of units in both the manufacturing and service sectors. 6 Increase in the (a) number of business units assisted (through loan facility), (b) amount of loan sanctioned, (c) amount of loan disbursed, (d) amount of loan recovered, etc., are some of the indicators of its growth and expansion. It has assisted, since its inception, about 1,70,355 industrial units to the tune of $11,387.48$ crores of which more than $50 \%$ is to MSMEs.

\section{Objectives of the Study}

In the light of the above, this paper makes an attempt to evaluate the performance of the corporation. Of course, it is very difficult to assess the performance of KSFC from different dimensions in a single paper. Hence, this paper focuses on the evaluation of performance of the corporation in terms of units assisted, amount of assistance, number of new entrepreneurs assisted besides the financial performance covering interest income, interest expense, net interest spread, profit after tax, etc.

\section{Literature Survey}

Many a number of researchers, academicians and professionals have worked on different dimensions of banking and financial institutions in the past focusing on one or the other aspects. However, an attempt is made here to review a few important studies to obtain an idea about different dimensions of the earlier studies - both in Indian and foreign context.

Analyzing the role of small and medium enterprises (SMEs) in India, Guntur Anjana Raju \& Mythili Kurpad (Summer 2013) observed that these enterprises have not been able to utilize their full potential owing to many a number of reasons such as stiff competition from large scale organizations, inadequate infrastructure, lack of skilled manpower, limited utilities, rural domination, etc. However, the important reason is the 'financial gap' - i.e., demand for financial assistance by SMEs exceeding the supply of the same by the financial institutions. though SMEs in Europe are at the heart of the economy and financed primarily by the banking institutions, the regulatory measures taken in the past have deeply affected financing SMEs - felt, Jocelyne Bendriss, Bertrand Lavayssière \& Mark Tilden (June 2014).

Though a number of schemes have been formulated and implemented by the governments for the promotion/development of small scale industries (SSIs), many a number of units are facing the financial problem. It may be noted here that the commercial banks are also lending, whatever little amount they can, to these SSIs. In this background and with the primary objective of evaluating the recovery management of commercial banks' loans to small SSIs, Parameshwara (2015) selected 466 SSIs in Dakshina Kannada and Udupi districts (Karnataka). As is known very well, prompt recovery of loan advanced by the banks is a necessity from the points of view of liquidity, ability to lend, security of assets and profitability of banks. However, the banks which have provided financial assistance to these units are facing many problems about the recovery of their loans from SSIs. Hence, he felt that it is necessary for the banks to strengthen their debt recovery mechanism and also to follow aggressive credit appraisals by the lending banks.

Profitability of banks depends upon their 
alertness, creation of large volume of performing assets, customer orientation, operational efficiency, working at optimal level, etc. Another crucial variable of successful functioning of banks is their ability to build up large volumes of quality assets while complying with the prudential norms (including maintenance of specified level of capital adequacy on risk assets). Further, productivity and efficiency play an important role in the banking industry, and this is more so in this competitive world. Continuous upgradation at all levels, commitment to the vision and mission of banks require the attention of banks in future. And in all likelihood, Vibha Jain (2007) felt, only the banks which are pro-active responding quickly to the changing needs of customers with due attention for the changing scenario will survive and prosper in this competitive world.

Profitability of 16 Indian banks selected for a study by Harish Kumar Singla (February 2008) was found to be reasonable during 2000-01 to 2006-2007 when compared to the previous years. Return on Investment which is considered as the overall profitability indicator was at a moderate rate. With regard to DebtEquity position, they maintained 1: 1 ratio though it was very high for some period. Though Capital Adequacy Ratio was constant, Interest Coverage Ratio registered a continuous increase. It was found that Return on New Worth had a negative correlation with the DebtEquity Ratio. Besides, Interest Income to Working Funds also had a negative association with the Interest Coverage Ratio. Further, nonperforming assets (NPAs) to Net Advances was negatively correlated with the Interest Coverage Ratio.

A SWOT analysis of Australian banks by Harad Jain \& Craig Bennett (December 2006) reveals that major banks are among the most profitable banks globally. This is attributed to robust industry regulation and transparent accounting policies and practices, and adequate capitalization supported by good quality residential mortgages which account for a higher proportion of major banks' balance sheets. However, intense competition in both loans and deposits segments resulting in compressed net interest margins, and risk of a moderate increase in NPAs owing to softening of economic conditions are the major weaknesses of Australian banks.

After examining the working of Development Financial Institutions (DFIs), Karunagaran A (2005) is of the opinion that the time is running out for the weak DFIs. Further, he observed that these DFIs should not be mere channels of credit, but they should have a proper system of risk appraisal and be able to evaluate each project or borrower. Srinivas, K. T (2013) made an attempt to examine the total financial assistance and the number of units assisted by KSFC in Karnataka during the study period of eight years. Based on the performance statistics, the author concludes that the work of KSFC is commendable in promoting enterprises for the economic development.

On the lines of the above, many a number of researchers have worked on different dimensions of both the MSMEs and financial institutions. These studies examine the problems of MSMEs on the one hand and the role of financial institutions in financing MSMEs on the other. However, one common observation is the problems of MSMEs in obtaining timely and adequate financial assistance. The financial difficulties of MSMEs are acknowledged even by the Finance Minister Sri Arun Jaitley (11 August 2016) who expressed the view that the credit availability is a challenge for the MSME sector. 


\section{Scope of the Study}

The unit of study is the Karnataka State Financial Corporation (KSFC) covering all its four circles and 32 branch offices. The study period cover eight years, 2008-09 to 2015-16. Further, the functional areas of the study include an evaluation of units assisted by the corporation, amount of financial assistance, new entrepreneurs assisted, etc., and also the overall financial performance. For the purpose of analysis of the data/performance statistics, simple analytical tools such as ratio, mean, percentage, etc., are used.

\section{Units assisted by KSFC}

The corporation, from the day of inception, has been assisting the MSMEs in the state in their financial requirements. It provides term loans and advances, factoring advances, subscribes to the debentures of business enterprises, lease finance and provides deferred payment and financial guarantee. Of these financial services, provision of term loans and advances to MSMEs is the core business of the corporation. However, before looking into these aspects, a few details about the number of units assisted by the corporation are presented below (Table -1$)$.

Table - 1: Number of Units Assisted

\begin{tabular}{|c|r|r|r|r|r|r|r|}
\hline \multirow{2}{*}{ Year } & \multicolumn{3}{|c|}{ Number of new Entrepreneurs assisted } & \multicolumn{2}{c|}{$\begin{array}{c}\text { Other } \\
\text { Units - } \\
\text { Existing }\end{array}$} & $\begin{array}{c}\text { Grand } \\
\text { Total }\end{array}$ \\
\cline { 2 - 7 } & $\begin{array}{c}\text { Micro and } \\
\text { Small Scale }\end{array}$ & SRTOs $^{8}$ & $\begin{array}{c}\text { Medium } \\
\text { Scale }\end{array}$ & Others & Total & - & 1,420 \\
$2008-09$ & - & - & - & - & - & - & 1,461 \\
$2009-10$ & - & - & - & - & - & 1,002 & 1,537 \\
$2010-11$ & 432 & 46 & 14 & 43 & 535 & 867 & 1,485 \\
$2012-13$ & 472 & 55 & 40 & 51 & 618 & 867 \\
$2013-14$ & 433 & 63 & 15 & 104 & 615 & 983 & 1,598 \\
$2014-15$ & 350 & 41 & 12 & 73 & 476 & 950 & 1,426 \\
$2015-16$ & 291 & 41 & 27 & 22 & 381 & 711 & 1,092 \\
8 -year Total & 355 & 35 & 36 & 35 & 461 & 650 & 1,111 \\
\cline { 2 - 7 } & 2,333 & 281 & 144 & 328 & 3,086 & 5,163 & 11,130 \\
6/8-year Average & 389 & 47 & 24 & 54 & 514 & 860 & 1,391 \\
\hline
\end{tabular}

Note: Details about the number of new units assisted during 2008-09 and 2009-10 are not available

Source: Table compiled with the help of the relevant data collected from Annual Reports and Operational Statistics, KSFC, 2008-09 to 2015-16.

From the above, it is unequivocal that the corporation has been encouraging and assisting industrial units in their financial requirements. Though there is no consistency in the performance of the corporation from one year to another, it is commendable to note that it has sanctioned (gross) loans and advances to 3,086 new units during the last six years. The new 
units for which gross sanctions have been made work out to 27.73 per cent of the total number of units for gross sanctions are made. Of the 3,086 new units, 75.60 per cent (i.e., 2,333 units) are micro and small (MS) scale industrial units. Besides 3,086 new projects, the corporation has also sanctioned loans and advances to another 5,163 existing units in their expansion and modernization programmes during the last six years. Of course, for the first two years of the study period viz., 2008-09 and 2009-10, the split details are not available. However, during these two years, the corporations sanctioned loans and advances to 2,881 units. Further, the corporation is providing priority to SC/ST and women entrepreneurs, and entrepreneurs from minority community. For example, during 2015-16, out of 1,111 units for which loans and advances have been sanctioned, 726 entrepreneurs are from these three categories - $385 \mathrm{SC} / \mathrm{ST}$ entrepreneurs, 258 women entrepreneurs and 83 entrepreneurs from minority community. These units have produced goods and services worth ₹ 2,439.01 crores during 2015-16. However, inconsistency in the number of new units and total number of units for which loans and advances have been sanctioned by the corporation becomes clear from the following figure (Figure -1).

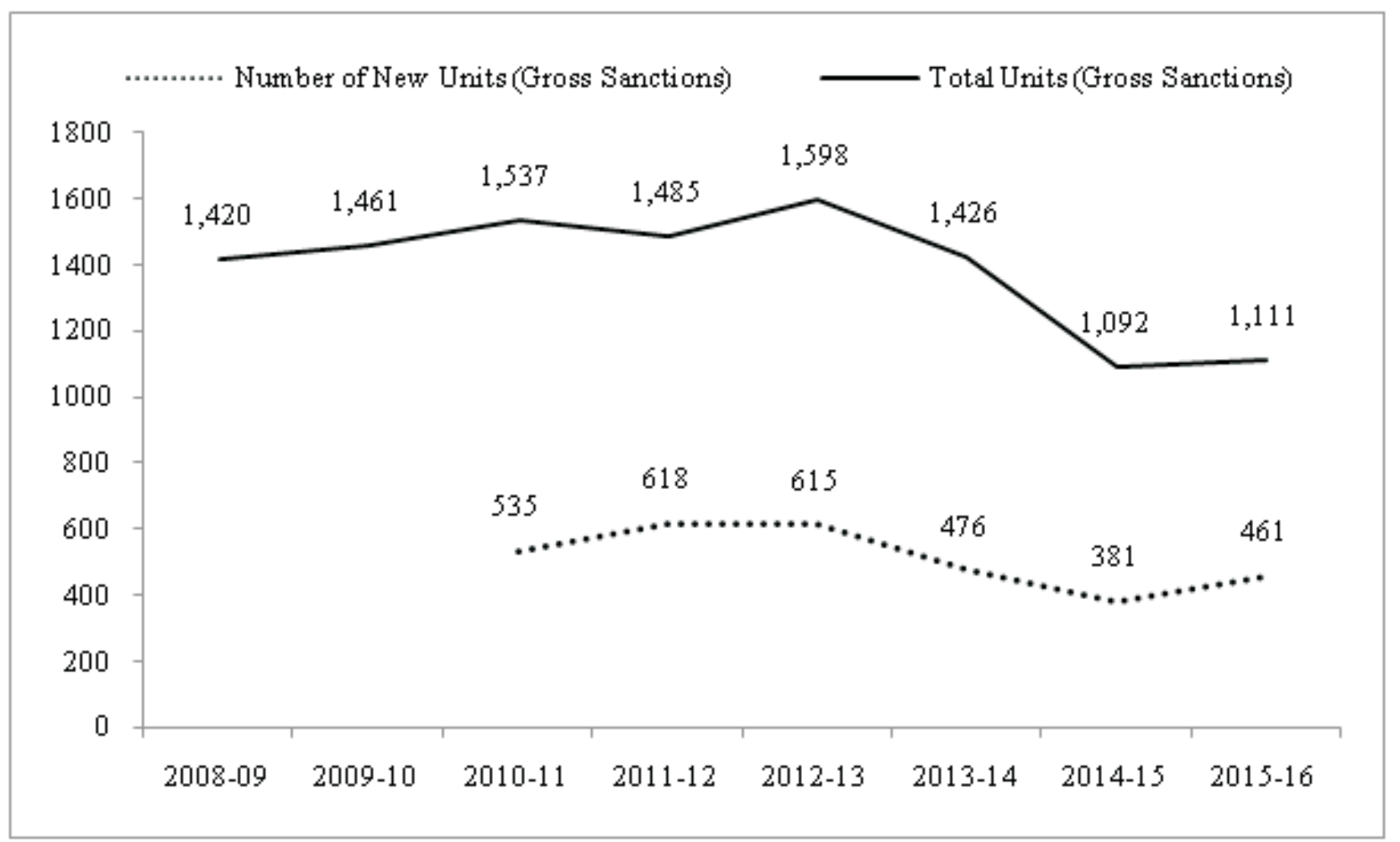

Figure - 1: Number of Units for which Loans Sanctioned - New and Total

\section{Amount of Financial Assistance}

The corporation has developed a comprehensive methodology not only for evaluating the proposals from the industrial units before according administrative sanctions, but also for appraisal of the projects during their life cycle. It examines all types of risks such as financial risks, business risks, managerial risk, legal risk, etc. All proposals from the industrial units for loans exceeding ₹ 1.5 crores each are examined and rated by its Risk Management Department. And the loan proposals exceeding ₹ 5 crores are placed before the Credit Risk Management Committee 
for its evaluation and opinion. Further, even before the disbursement of first instalment of loan, the corporation undertakes a rigorous evaluation of viability of project and also further documents submitted. Only when it is satisfied about the viability, the corporation starts disbursing loans sanctioned in phased manner. Therefore, the amount of loans disbursed is usually lower than sanctioned in any financial year. In this backdrop, relevant details are presented below (Table -2$)$.

Table - 2: Year-wise Gross Sanctions and Disbursement of Loans

\begin{tabular}{|c|c|c|c|}
\hline \multirow{2}{*}{ Year } & \multicolumn{2}{|c|}{ Amount (₹ crores) } & $\begin{array}{c}\text { Percentage of } \\
\text { Disbursements to } \\
\text { Gross Sanctions }\end{array}$ \\
\cline { 2 - 3 } $2008-09$ & $\begin{array}{c}\text { Gross Sanctions } \\
\text { during the Year }\end{array}$ & $\begin{array}{c}\text { Disbursements } \\
\text { during the Year }\end{array}$ & 67.92 \\
$2009-10$ & 565.24 & 383.92 & 68.79 \\
$2010-11$ & 631.49 & 434.39 & 79.33 \\
$2011-12$ & 731.63 & 580.41 & 73.05 \\
$2012-13$ & 817.32 & 597.08 & 77.82 \\
$2013-14$ & 944.06 & 734.70 & 77.81 \\
$2014-15$ & 909.26 & 707.47 & 82.00 \\
$2015-16$ & 675.15 & 553.62 & 77.38 \\
\cline { 2 - 3 } Total/Average & $6,006.09 / 750.76$ & $4,557.95 / 569.74$ & 75.89 \\
\hline
\end{tabular}

Source: Table compiled on the basis of the data collected from Annual Reports and Operational Statistics, KSFC, 2008-09 to 2015-16.

It is obvious from the above that the amount of loans sanctioned registered a continuous increase till the end of 2012-13 and thereafter, it moved in both the directions. However, the amount of loans sanctioned increased from ₹ 565.24 crores in 2008-09 to ₹ 944.06 crores during 2012-13 and then started declining reversing this declining trend in the last year of study period during which the corporation sanctioned 731.94 crores. During this 8-year period, it sanctioned ₹ $6,006.09$ crores (to 11,130 units) working out to an annual average of ₹ 750.76 crores. Even in the case of amount of loans disbursed, a similar type of trends can be observed - increasing initially, then declining and finally ending up with marginal improvement (when compared to immediately preceding year). However, as already pointed out, the amount of loans disbursed has always been lower than that of sanctioned. The percentage of amount of loan disbursed to the amount of loan sanctioned varied between 67.92 (2008-09) and 82 (2014-15). On an average, the corporation disbursed only 75.89 per cent of loan amount sanctioned. During this 8-year period, the disbursed ₹ 4,557.95 crores which works out to an annual average of ₹ 569.74 crores. However, these fluctuations (i.e., trends) and also the gap between loan amount sanctioned and disbursed become very clear from the following pictorial presentation (Figure-2). 


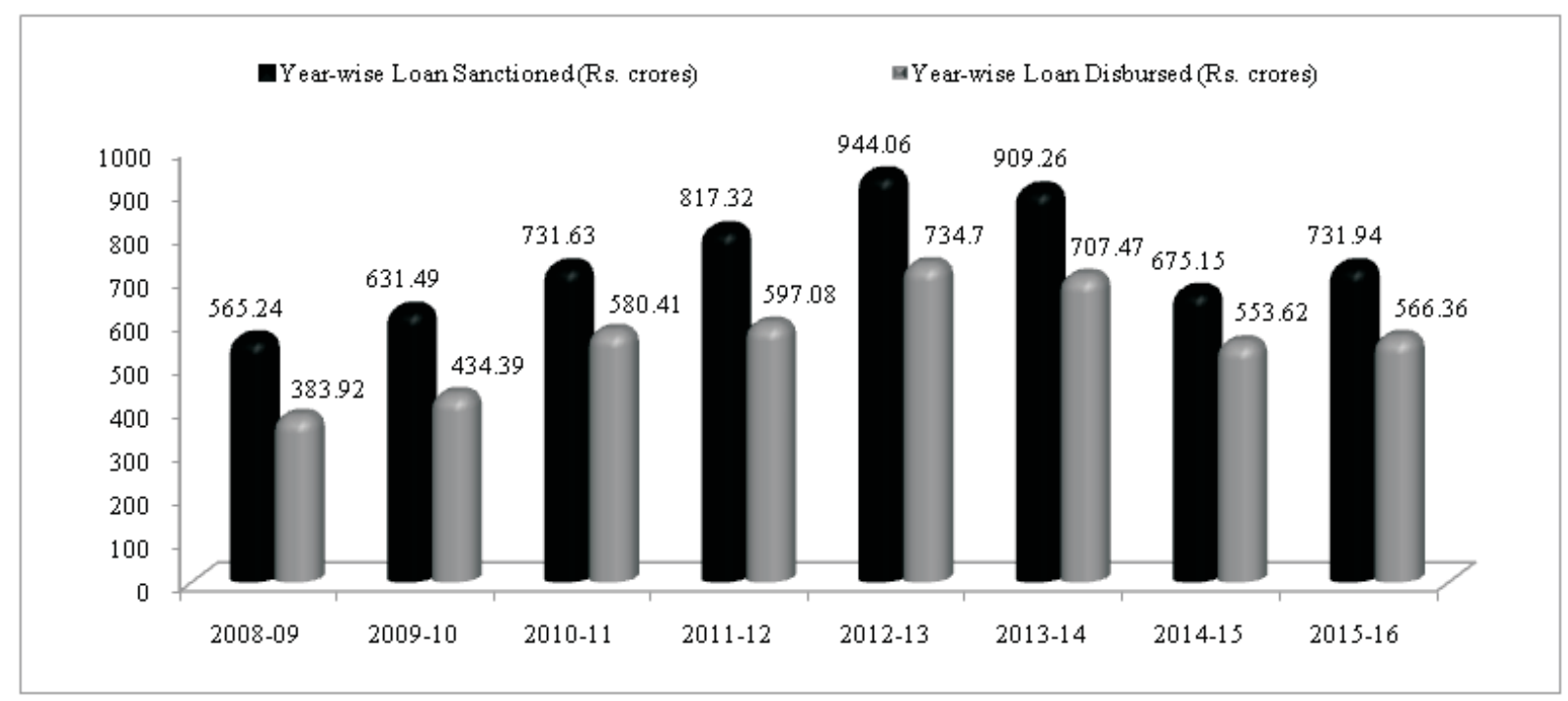

Figure - 2: Loan Sanctioned and Disbursed, and Fluctuations

Further, the corporation sanctioned small amounts of loans (say, less than ₹ 10 lakhs per industrial/business unit) to more than $₹ 5$ crores per unit depending upon their requirements and the satisfaction of conditions for availing of the loan facility. During this 8-year period, 1,453 units were sanctioned less than ₹ 10 lakhs of loan each and the average working out to ₹ 0.0777 crore (i.e., ₹ 7.77 lakhs). On the other hand, for only 221 units, more than ₹ 5 crore each of loan was sanctioned for during this 8year period working out to an average of ₹ 4.4056 crores per unit. The remaining units were sanctioned loans ranging from ₹ 10 lakhs to $₹ 5$ crores each as evident from the data presented in the annexure (Annexure - 1). However, what is evident from the contents of the annexure is that the number of units seeking lower amounts of loans has been decreasing over the years (e.g., number of units for which less than ₹ 10 lakhs each of loan sanctioned declined from 424 in 2008-09 to 76 during 2015-16) followed by increase in the number of units seeking higher amounts of loans (e.g., number of units for which more than 5 crores each of loan sanctioned increased from 9 in 2008-09 to 34 during 2015-16). However, this extension of loans and advances has enabled the corporation to improve its profitability year after year in the recent past as evident from the following analysis.

\section{Net Interest Spread}

As is known very well, the corporation borrows money from a few sources and accepts fixed deposits in accordance with Section 8 of The State Financial Corporations Act, 1951. On these borrowings and fixed deposits, it pays the interest at the agreed rate and this interest payment by the corporation to its lenders/ depositors constitutes the 'interest expense' of the corporation. The term borrowings, fixed deposits, etc., so mobilized is used for its lending activities on which it earns interest, and this constitutes the 'interest income' of the corporation. This interest income constitutes major part of the corporation's income ranging from 75 - 90 per cent. The difference between the interest income and the interest expense is called 'net interest spread' 9 as presented below.

$$
\underset{\text { Net Interest }}{\text { Spread }}]=\left[\begin{array}{l}
\text { Interest } \\
\text { Income }
\end{array}\right]-\left[\begin{array}{c}
\text { Interest } \\
\text { Expense }
\end{array}\right]
$$


This spread is an important indicator of profitability of the corporation as it is from this spread (and other incomes) that the corporation meets all other expenses and obligations, and earns some surplus as net profit after tax (Table - 3).

\section{Table - 3: Few Financial Performance Statistics}

\begin{tabular}{|c|c|c|r|r|r|r|}
\hline \multirow{2}{*}{ Year } & \multicolumn{3}{|c|}{ Amount (₹ lakhs) } & \multicolumn{3}{|c|}{ Percentage of Increase ${ }^{10}$ in, } \\
\cline { 2 - 6 } & $\begin{array}{c}\text { Interest } \\
\text { Income }\end{array}$ & $\begin{array}{c}\text { Interest and other } \\
\text { Financial Expenses }\end{array}$ & $\begin{array}{c}\text { Interest } \\
\text { Spread }\end{array}$ & $\begin{array}{c}\text { Interest } \\
\text { Income }\end{array}$ & $\begin{array}{c}\text { Interest } \\
\text { Expense }\end{array}$ & $\begin{array}{c}\text { Net Interest } \\
\text { Spread }\end{array}$ \\
\hline $2008-09$ & $16,923.76$ & $16,384.22$ & 539.54 & - & - & - \\
$2009-10$ & $18,214.48$ & $13,706.49$ & $4,507.99$ & 7.63 & -16.34 & 735.52 \\
$2010-11$ & $19,868.38$ & $14,391.03$ & $5,477.35$ & 9.08 & 4.99 & 21.50 \\
$2011-12$ & $20,382.09$ & $15,887.36$ & $4,494.73$ & 2.59 & 10.40 & -17.94 \\
$2012-13$ & $24,665.85$ & $18,426.77$ & $6,239.08$ & 21.02 & 15.98 & 38.81 \\
$2013-14$ & $25,478.98$ & $19,305.56$ & $6,173.42$ & 3.30 & 4.77 & -1.05 \\
$2014-15$ & $26,352.25$ & $15,862.64$ & $10,489.61$ & 3.43 & -17.83 & 69.92 \\
$2015-16$ & $27,449.52$ & $16,009.04$ & $11,440.48$ & 4.16 & 0.92 & 9.06 \\
8-year Total & $1,79,335.31$ & $1,29,973.11$ & $49,362.20$ & & & \\
\cline { 2 - 5 } 8-year Average & 22416.91 & 16246.64 & 6170.28 & \multicolumn{3}{|c}{} \\
\hline
\end{tabular}

Source: Table compiled on the basis of the data collected from Annual Reports and Operational Statistics, KSFC, 2008-09 to 2015-16.

It is obvious from the above that the corporation has succeeded in improving its interest income incessantly year after year. One of the reasons for this continuous increase in the interest income is the increase in amount of loans and advances made to the industrial units. It increased its interest income from ₹ $16,923.76$ lakhs in 2008-09 to ₹ $27,449.52$ lakhs in the last year of study period representing an increase by ₹ $10,525.76$ lakhs which works out to an increase by 62.20 per cent. However, there is no consistent improvement in the rate of increase in the interest income. For example, during 2009-10, it earned 7.63 per cent higher interest income (when compared to 2008-09) but allowed it to decline to 2.59 per cent in 2011-12 (compared to 2010-11). During 2012-13, the rate of increase was 21.02 per cent which is the highest rate of increase in any of the years of the study period. Again it declined to 3.30 per cent in 2013-14 and thereafter has been a marginal improvement in the interest income.

Similarly, the corporation achieved mixed success from the point of view of interest expense. One of the reasons for decline in the interest expense, for example, during 2014-15 (when compared to 2013-14) is the reduction in the term borrowings. However, for majority of the years, the interest expense amount is higher than the immediately preceding year. As a result, the rate of increase is both positive (for majority of the years of study period) and negative (for two years - indicating reduction in the absolute amount of interest expense). As a result of these, there has been a continuous fluctuation in the rate of change in the net interest spread. During 2009-10, the rate of increase is highest among all other years of the study period at 7.36 times. Of course, one of 
the reasons for this substantial increase is the very low net interest spread in the base year viz., 2008-09. However, the direction of changes in the interest income and interest expense becomes clear from the following figure (Figure -3$)$.

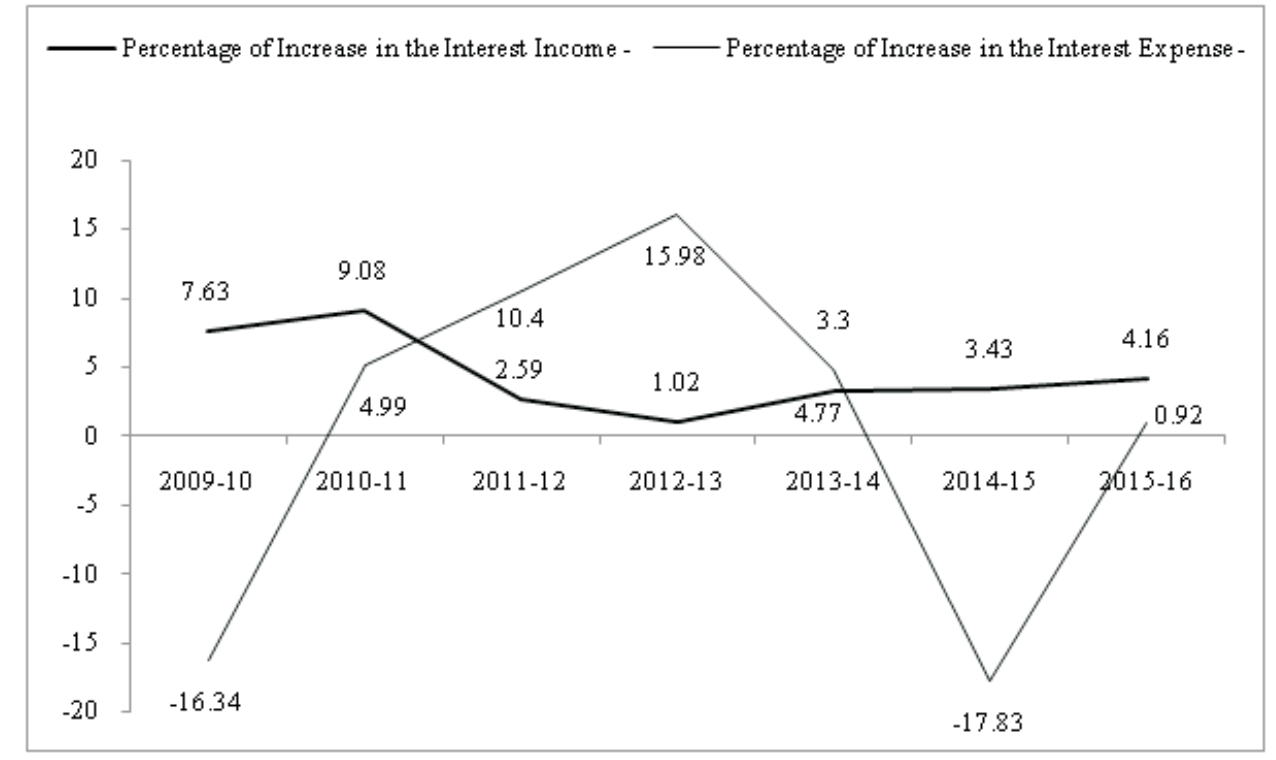

Figure - 3: Trends in Interest Income and Interest Expense

\section{Profit, Accumulated Loss, etc.}

With the help of its judicious lending and other activities, and economical mix of borrowings and fixed deposits, the corporation has been able to earn profit continuously with two exceptions incurring loss in 2008-09 and inconsistency in the amount of post-tax profit earned and reported. This is evident from few relevant statistics presented below (Table -4$)$.

Table - 4: Profit, Accumulated Loss, etc.

\begin{tabular}{|c|c|r|c|}
\hline \multirow{2}{*}{ Year } & \multicolumn{3}{|c|}{ Amount (₹ lakhs) } \\
\cline { 2 - 4 } & $\begin{array}{c}\text { Loss Brought } \\
\text { forward }\end{array}$ & $\begin{array}{c}\text { Profit after } \\
\text { Tax }\end{array}$ & $\begin{array}{c}\text { Deficit carried to } \\
\text { Balance Sheet }\end{array}$ \\
\hline $2008-09$ & $53,874.50$ & $-3,984.09$ & $57,858.59$ \\
$2009-10$ & $57,858.59$ & 296.15 & $57,562.44$ \\
$2010-11$ & $57,562.44$ & $2,187.14$ & $55,375.30$ \\
$2011-12$ & $55,375.30$ & $1,109.02$ & $54,266.28$ \\
$2012-13$ & $54,266.28$ & $1,702.49$ & $52,563.79$ \\
$2013-14$ & $52,563.79$ & $1,141.88$ & $51,421.91$ \\
$2014-15$ & $51,421.91$ & $4,446.98$ & $46,974.93$ \\
$2015-16$ & $46,974.93$ & $3,213.06$ & $43,761.87$ \\
Total & & $10,112.63$ & \\
\hline
\end{tabular}

Source: Table compiled on the basis of the data collected from Annual Reports and Operational Statistics, KSFC, 2008-09 to 2015-16. 
Though the corporation has been earning profit for all the years of the study period (except the first year, 2008-09), the problem of the corporation is its huge past losses which is brought forward. Till the beginning of 2008-09, the corporation suffered a total loss ${ }^{11}$ (after part recovery out of profits earned in some years prior to 2008-09) ₹ 53,874.50 lakhs. Again, for 2008-09, it suffered a loss of ₹ 3,984.09 lakhs causing the accumulated loss to increase to ₹ 57,858.59 lakhs by the end of 200809. Thereafter, there has been a continuous profit enabling the corporation to lower its accumulated loss. During the last seven years, it earned a post-tax profit of ₹ 14,096.72 lakhs and this has helped the corporation to lower its accumulated loss from ₹ 57,858.59 lakhs to ₹ 43,761.87 lakhs representing a reduction by 24.36 per cent. This continuous reduction in the amount of accumulated loss of the corporation becomes clear from the following figure (Figure -4$)$.

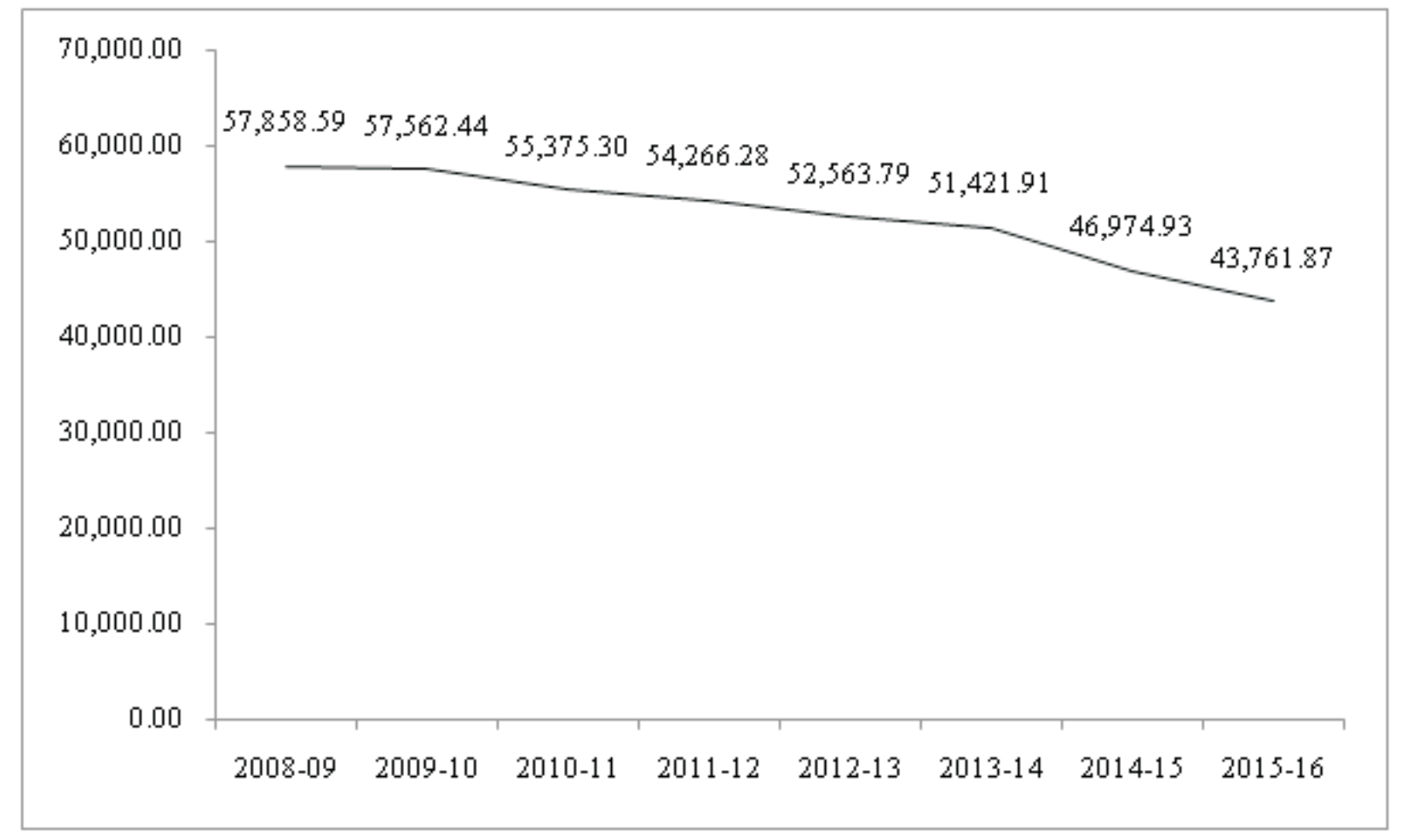

Figure - 4: Accumulated Loss ('lakhs)

\section{Conclusion}

It is obvious from the above factual analysis that the corporation, in spite of constraints, has been doing a commendable job of assisting MSMEs in the state. However, the major problem of the corporation is its accumulated loss. Even if it continues to earn profit after tax at the current level of ₹ 35 - ₹ 40 crores annually in future, it needs another $11-13$ years to wipe out the entire accumulated loss. Therefore, it is necessary for the corporation to undertake the credit appraisal rigorously and on continuous basis throughout the life cycle of the projects assisted, and also to strengthen its recovery mechanism.

\section{Notes}

1. This was set up as an apex institution in the area of industrial finance in 1964 by an 
Act of Parliament. However, IDBI was merged with IDBI Bank on 2 April 2005.

2. With the support from Government of India, World Bank, Commonwealth Development Finance Corporation and other foreign financial institutions, ICICI was established in 1955 as a joint stock company. However, it (i.e., ICICI) was merged with ICICI Bank on 30 March 2002.

3. IFCI was the first development financial institution established in the country by the Government of India (GoI) on 1 July 1948. It was restructured in October 1999 from a statutory corporation to a company form (as IFCI Ltd) under the Indian Companies Act, 1956.

4. The four circles are, Circle - I (Bengaluru Circle), Circle - II (Mysuru Circle), Circle
- III (Dharwad Circle), Circle - IV (Kalaburgi Circle),

5. Zonal office mechanism was introduced in 1987 and it was in vogue up to 2 April 2012 .

6. KSFC provides loans and advances to all types of industrial enterprises except a few prohibited lines such as nitro glycerin based industrial explosives, khandasari sugar, etc.

7. Subsequent to an amendment to the Government of India (Allocation of Business) Rules, 1961, the erstwhile Ministry of Small Scale Industries, and the Ministry of Agro and Rural Industries were merged to form the Ministry of Micro, Small and Medium Enterprises.

8. 'SRTOs' stands for Small Road Transport Operators.

9. This meaning is based on the meaning of Net Interest Rate Spread which represents the difference between the average rate at which a financial institution borrows and the average rate at which it lends money. It is normally computed by using the following formula.

$\begin{aligned} & \text { Net Interest } \\ & \text { Rate Spread }\end{aligned}=\left[\frac{\text { Interest Income }}{\text { Interest Earning Assets }}\right]-\left[\frac{\text { Interest Expense }}{\text { Borrowings and Other Liabilities bearing Interest }}\right]$

10. Percentage of increase is computed by considering the amount in the immediately preceding year as the base.

11. Of course, even prior to 2008-09, the corporation earned profit for some years. But this profit was not adequate to recover the loss suffered in other years prior to 2008-09. Hence, it brought forward the loss to 2008-09 and subsequent years.

\section{References}

- Arun Jaitley. (11 August 2016). Business Line. Mangaluru. P. 3
- Guntur Anjana Raju \& Mythili Kurpad. (Summer 2013). SME securitization: A new ray of hope for SMEs in India. Journal of Structured Finance. 19(2): pp. 89-119.

- Harad Jain \& Craig Bennett. (December 2006). Bank industry risk analysis: Australia. Economic Papers. pp. 88-102.

- Harish Kumar Singla. (February 2008). Financial performance of banks in India. ICFAI Journal of Bank Management. 7(1): pp. 50-62. 
- Jocelyne Bendriss, Bertrand Lavayssière \& Mark Tilden. (June 2014). Financing SMEs: Needed innovations are emerging. Revue d'Économie Financière. Vol. 114: pp. 241-52 (based on translated version from French to English).

- Karunagaran A (March 2005). Should DFIs be Revivedfi. Economic and Political Weekly, 40(12): pp. 1247-53.

- Parameshwara. (2015). Recovery management of commercial bank loans to small scale industries - A study in Dakshina Kannada and Udupi districts. Thesis submitted to Mangalore University (unpublished).

- $\quad$ Prime Minister's Task Force. (2010). Report of prime minister's task force on micro, small and medium enterprises.
Ministry of Micro, Small and Medium Enterprises. Government of India. p. 7 retrieved on 10 October, 2014 from http://msme.gov.in/WriteReadData/Docum entFile/ PM_MSME_Task_Force Jan2010.pdf

- Ruchika Jeswal. (2012). Role of SME in Indian economy, National Conference on Emerging Challenges for Sustainable Business 2012. p. 291 (Conference Proceedings).

- Srinivas K T. (November 2013). A Study on Financial Assistance to Small and Medium Enterprises by KSFC. Abhinav. Volume II, pp. 20-30.

- Vibha Jain. (2007). Non-performing assets in commercial banks. Regal Publications, New Delhi. 
Size-wise Gross Sanctions - Total and per Unit

Annexure - 1

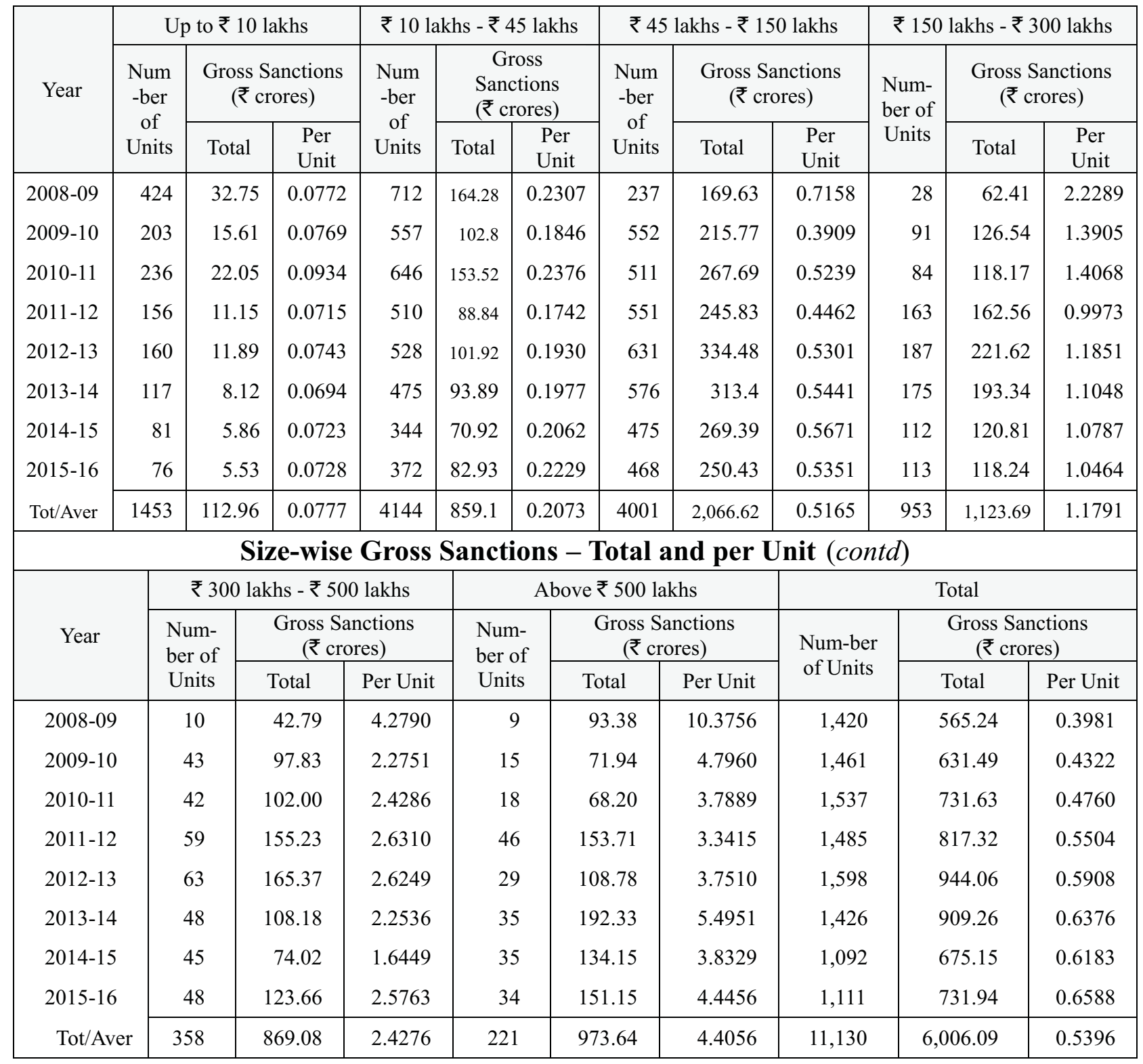

Source: Annexure compiled on the basis of the data collected from Annual Reports and Operational Statistics, KSFC, 2008-09 to 2015-16. 